\title{
Developing Thinking Skills Among Students Towards Creating Quality Human Capital
}

\author{
Muhamad Ezzul Esa ${ }^{1}$, Mohd Mahzan Awang ${ }^{2}$, Abdul Razaq Ahmad ${ }^{3}$ \& Anuar \\ Ahmad $^{4}$ \\ ${ }^{1234}$ Faculty of Education UKM, MALAYSIA
}

E-mail: ezzul@mara.gov.my

\begin{abstract}
This paper is intend to discuss the implementation of Thinking Skills among students towards the development of quality human capital. The main focuses of this paper is to look at Thinking Skills in terms of curriculum, pedagogy and assessment while implementing the Learning and Facilitation Process (PdPc) to build quality human capital among students. The concepts of Critical and Creative Thinking Skills (CCTS) and High Level Order Thinking Skills (HOTS) will also be explore to make comparisons between the two in developing quality human capital. The comparison is in terms of the effectiveness of the CCTS and HOTS in the development of student human capital. The effectiveness of HOTS will also be compare between different southeastern Asian countries to assess the extent to which the impact of the present-day HOTS has been widely discussed in the country. Quality human capital formation is closely relate to education. Referring to Schultz's theory of human capital development, 1971, In general, it explains the importance of education in developing longterm humanity in the interests of the national economy. The discussion of this paper refers to relevant journals, theories and concepts and scientific papers. The results of this paper are expecte to assist various parties in generating and developing human capital among students in the future. An effective education system will produce quality human capital.
\end{abstract}

Keywords: HOTS, Critical and Creative Thinking Skill, Human Capital Theories

\section{Introduction}

The Malaysian Education Development Plan (PPPM) 20132025) outlined six student aspirations that needed to be achieved namely knowledge, thinking skills, leadership skills, bilingual skills, national identity and ethics and spirituality. It is clear that PPPM intends not only focus on the success of the system, but also aims to produce high quality students in the future. One of the things that stands out in the PPPM is the thinking skills that have evolved over the years. As such, these thinking skills are in line with the six aspirations of the PPPM introduced in 2013 to address 21 st century learning and teaching. The thinking and developmental skills of the education system in Malaysia started with the Critical and Creative Thinking Skills (CCTS) which has evolved into the Higher Lever Order Thinking Skills (HOTS). 
Beginning with Critical and Creative Thinking Skills (CCTS) introduced in 1994 through the Primary School Integrated Curriculum and the High School Integrated Curriculum. The CCTS was introduce to create students capable of learning in the 21 st century today. These Thinking Skills emphasize that students can solve problems using appropriate, non-rush and effective thinking. The importance of implementing the KBAT is to provide students with the ability to develop and develop good and effective thinking, to adopt a critical and creative thinking culture and to avoid thinking and making mistakes.

Subsequently, thinking skills continued to evolve and evolved into Higher Level Order Thinking Skills (HOTS) introduced by the Ministry of Education (MOE) under the Curriculum Development Division in 2013 to enhance the implementation of thinking skills in the education system in Malaysia. HOTS is implemented using a holistic approach to the school system in Malaysia through a three-pronged approach namely curriculum, pedagogy and assessment as well as four supporting elements namely cocurriculum, community and private support, resources and finally capacity building. Just memorizing and memorizing techniques without understanding a single issue and avoiding them is one of the main purposes of HOTS being introduced in the school system in Malaysia. MOE wants to produce students who are capable of solving problems and situations by mastering the skills of assessing, applying, analyzing and creating. These four skills are the four highest levels of the theory of bloom taxonomy introduced by Benjamin Bloom.

The development of these thinking skills is one of the ways to provide quality students in the future. Quality students not only intellectual but also need quality in terms of value and human capital formation. The development of human capital undertaken by the MOE has greatly contributed to the development of human capital in the education sector. Human capital development is very important for students so that Malaysia can create a society that can improve the country's economy. This is because one of the developments of human capital is highlighted by Schultz's 1971 theory of human capital development emphasizes on education and training as well as health and keconomic aspects.

Therefore, the evolution of thinking skills is one of the developments and evolution of education system in Malaysia is the development of human capital for students. The allocation of money to change a system can sometimes cost a bit too much. The quality of education emphasized in Schultz's theory of human capital development is good and helps the country to improve its economy in the long run. In order to achieve efficient and effective productivity and labor, investment must be made on that input so that good quality can be apply from the start. The inputs are made-up of students who have been educated from the beginning.

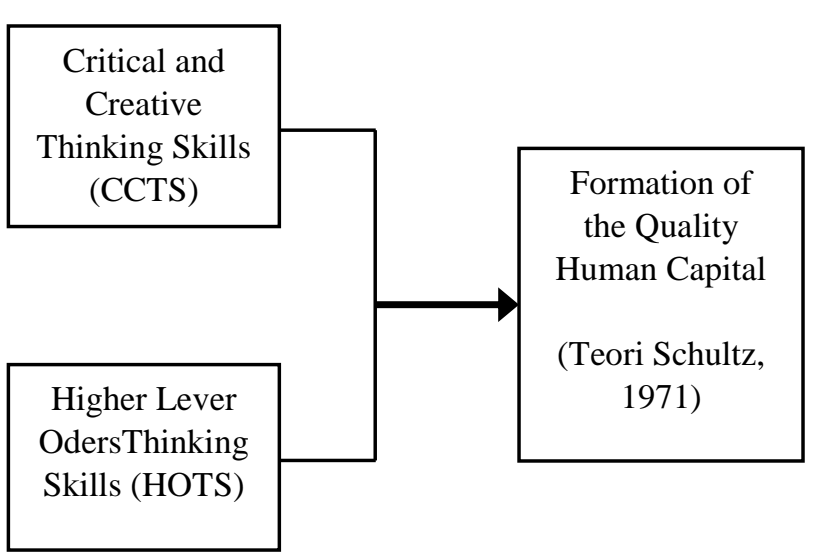

Figure 1 Conceptual Framework

Figure 1 shows the conceptual framework of the study to be use in this paper. The conceptual framework shows that current thinking skills that have been developed into two parts, Critical and Creative Thinking Skills (CCTS) and High Orders Level Thinking Skills (HOTS) will influence the formation of human capital by referring to Schultz 1971. Theory and the effectiveness of the thinking skills introduced in 1994 and 2013 has the potential to give an impacted the development of quality human capital among students. The difference between these two skills will also have a different impact on students' human capital due to their different implementation and importance. This is because, despite its implementation and importance, the main goal that we want to achieve is to produce people in particular and a quality society and to benefit Malaysia in many ways, especially economically.

\section{Problem Statement}

Quality human capital is one of the main pillars for a country. To ensure the prosperity and well-being of a nation, human capital development needs to be enhanced from time to time in order for it to continue. In Malaysia, human capital development was initiated by former $5^{\text {th }}$ Malaysian Prime 
Minister the Honorable Tun Abdullah Haji Ahmad Badawi in presenting the Rancangan Malaysia Ke-9 (RMK-9) in 2006. According to YAB Tun Abdullah Haji Ahmad Badawi's speech in the $48^{\text {th }}$ Independence Day message of 2005, "To develop human capital, we want to provide enough knowledge, we want to educate them to be a nation of high-quality, high-minded, high-spirited, love-loving countries and they also have the physical strength and spiritual power. We must be the people who love this country, the people who are passionate, willing to work hard, work diligently and be high-quality citizens."

According to Abd. Hair Awang, Rahmah Ismail and Zafir Mohd. Makhbul (2009), human capital is something that is own by humans that make it better. Macro-long-term investments in efforts to raise quality human capital require programs such as education, training, migration and health. It is a strategy designed to achieve the goals of human resource planning. It is clear here that education plays a very important role in the development of quality human capital. The education system in Malaysia has undergone a wide range of changes and developments from various levels ranging from pre-primary, primary, secondary, tertiary and vocational levels. According to Nik Mustapha (2006), in order to achieve this level of harmony at the individual level, Islam prioritizes moral education so that the personality (personality) of the individual can be shaped by positive (can be influenced by a positive outlook) and good moral behavior. This effort is necessary in education that can help the understanding and undergo spiritual training to reduce negative behaviors hopefully.

An important factor in all economic activities is either human capital or human capital. The demands of the job market that require a variety of human resources have reflected the needs of human capital development in a country. This is because rapid economic growth is closely related to quality human capital. According to Venhorst et al. (2010), that human capital is the key to modern economic growth theory. This importance of education has led to the government's initiative to strengthen the education system through the allocation of national income for educational development purposes. The development of education, especially at the higher levels, is very important in the development of more productive human capital to enhance economic productivity. Furthermore, human capital building at this stage is at the core of generating a knowledge-based economy.

One of the developments and changes made in the education system in Malaysia is the development of thinking skills introduced by the Ministry of Education Malaysia. The introduction of Critical and Creative Thinking Skills (CCTS) initially changed the landscape of the Malaysian education system. Students have been encouraged to think critically and creatively in solving problems or situations. This will enable the education system to produce individuals who are able to meet the country's economic needs. Students who are mature and well thought-out will make one available to them with whatever challenges they may face in developing the country.

In addition, High Order Level Thinking Skills (HOTS) was introduced in 2013 as the result of the development of the HOTS was introduced earlier. This thinking skill is a skill that is inspired by the theory of Taxonomy Bloom, which is refers to the four highest levels of the theory of evaluating, applying, analyzing and creating. The four highest levels of bloom taxonomic skills, when acquired by students, will enable them to not only remember and understand what they are learning. However, they will be prepared to face whatever comes their way. With HOTS also the output or success of individual incarceration will be achieved for the future development of the country. Therefore, the effectiveness and importance of the CCTS and HOTS should enable the development of quality human capital among students in Malaysia. Of course, this approach to both thinking skills will also make a measurable difference in human capital development.

\section{Research Objectives}

Specifically, the objectives of this paper are to:

1) Identify the differences in curriculum approach, pedagogy and assessment emphasized in thinking skills to build quality human capital.

2) Identify the effectiveness of CCTS and HOTS in developing quality human capital.

3) Identify the effectiveness of HOTS in the education system between Malaysia, Indonesia and Singapore.

\section{Literature Review}

Education is a medium for shaping and developing the human capital of a country. No matter where else, education is very important for a country to give birth to a vibrant and fast-paced society. The National Curriculum aims to produce a balanced future for Malaysia and to master the 21st century skills. Students who master the 21 st century skills with critical, creative and innovative thinking and thinking skills are able to compete globally. These skills are in line with the six aspirations of students as stated in the Malaysian Education Development Plan (PPPM) where each student will have the knowledge, thinking skills, leadership skills, 
bilingual skills, ethic and spirituality and national identity (Curriculum Development Division, MOE, 2013).

Human capital is one of the most important investments in the development of a nation and is at the forefront of innovation and a high-income economy (Rancangan Malaysia Ke-10, 2011-2015). As such, high development and investment in human capital, especially at the tertiary level, has always been a priority of the Government in each of the five-year and medium-term plans (Muhammad Hazrul Ismail, 2012). Malaysia is no exception to making human capital development one of its development strategies. It is an effort to develop Malaysians as a cornerstone of future excellence. Based on the fundamental principles laid down by the government, the human capital we want to develop is a knowledgeable, confident, high moral and moral person, ethical, ethical, ethical, disciplined, dynamic, innovative, creative, healthy, patriotic, fair, progressive, blockbuster and competitive (Mohd Fauzi Hamat \& Mohd Khairul Naim Che Nordin, 2012). In the study of Norain Mat Lazim \& Nooriah Yusof, 2012, stated that the importance of education has led to the government's initiative to strengthen the education system through the allocation of national income for educational development purposes. The development of education, especially at the higher levels, is very important in the development of more productive human capital to enhance economic productivity. Furthermore, human capital building at this stage is at the core of generating a knowledge-based economy.

Among the development of human capital that has been achieve through education in Malaysia is the development of thinking skills that began with the CCTS and subsequently the HOTS are widely used today. Creative and Critical Thinking Skills (CCTS) need to be emphasized in the teaching and learning process (PdP) as students exposed to creative and critical thinking are better prepared to face more complex problems and be able to respond to technological changes that are taking place. This is because students have the ability and skills to act effectively through creative and critical thinking (Jamaliah Jakpar, 2015). According to the study of Norliza Binti Abdullah (2018), mastering, practicing and applying high level thinking skills for every student is crucial to realizing the dream and the nation's hope of producing perfect and quality human beings in line with the National Education Philosophy. Steps to build a nation with high-level thinking through the education received in schools are outline in the Malaysian Education Development Plan (2013-2025).

\section{Research Methodology}

According to Creswell (2005), study design is a procedure or method in quantitative or qualitative research in which the researcher conducts a survey of the sample or the entire population. In this paper, the research design used is the Library Research method. This method is to identify findings from past studies through reading journals, theories and concepts of scientific papers related to the thinking skills of the CCTS and HOTS in the development of quality human capital. The focus of the study is on the importance and effectiveness of the curriculum, pedagogy and assessment of the CCTS and HOTS on the development of quality human capital among students in Malaysia.

\section{Discussion}

\subsection{Differences in Critical and Creative Thinking Skills (CCTS) and High Orders Level Thinking Skills (HOTS)}

\subsubsection{Element of Curriculum}

The CCTS's curriculum are based on the Primary School Integrated Curriculum (KBSR) and the Secondary Integrated Curriculum (KBSM) was introduced and implemented in 1994 to support and support the National Education Philosophy. The implementation of the KBSM and the KBSR is in line with the goal of the nation's education towards producing competitive and balanced people in line with trust and obedience to God. KBSR and KBSM are based on the concept of Integrated Education. The concept has emphasized that it aims to further development of the individual's overall intellectual, spiritual, emotional and physical potential to produce knowledgeable, virtuous and virtuous people as well as serving the community and nation. The approach emphasized in KBSR and KBSM is more about student-centered education. In each KBSM and KBSR document issued by the Ministry of Education Malaysia (KPM), the Ministry of Education (MOH) emphasized that the CMS is use to implement this curriculum. In order to achieve this aspiration, quality science education must be provided so that the nation can produce knowledgeable, skilled and capable human capital to lead other international competitors in the advancement of science and technology (Director of Curriculum Development Division, KPM, 1993).

Meanwhile, the HOTS's curriculum is based on reference to the Primary School Curriculum (KSSR) and the Secondary School Curriculum (KSSM) was instituted and implemented in 2017. The KSSM was introduced as there is a need to make the National Curriculum more holistic and relevant to the need for the 21 st century to produce critical, creative and innovative human capital and to contribute to the development of the country and to compete internationally and globally. The KBSM curriculum 
framework is based on three key areas of communication, human and environmental as well as individual development. The KSSM curriculum framework, on the other hand, is based on six key areas of communication, physical \& aesthetic development, humanities, personal skills, Science and Technology (STEM) and attitude \& values.

It is clear here that the two thinking skills through the curriculum introduced are towards the development of quality human capital for students. It can be seen from the core of KBSM and KSSM that aspire to produce students who are capable of communicating, physically and emotionally stable, with human values, good self-esteem, comprehensive science and technology skills as well as praiseworthy attitudes and values, quality of human capital. Therefore, the development of human capital through the $\mathrm{CBC}$ and $\mathrm{CYC}$ is one of the good investments in human capital to meet the challenges of globalization today.

\subsubsection{Elements of Pedagogy}

Pedagogy is a process of teaching and learning that is art and science in the delivery of content. The process of teaching and learning takes place through the interaction of teachers and students, content and learning objectives. Shulman and Grossman (1987) outline that the knowledge that a teacher has and the way they present it is a dominant integration in ensuring that students receive dynamic and responsive learning. The Thinking Skills identified to be emphasize in the CCTS of teaching and learning process by the Ministry of Education are as follows: (a) comparing and contrasting, (b) making predictions, (c) explaining why, (d) categorizing, (e) triggering ideas, (f) defining reliable sources (g) generating metaphors, (h) producing analogies, (i) making assumptions, (j) defining sub-sections and overall, (k) making inferences, (l) making decisions and (m) solve the problem. There are five pedagogical challenges for implementing the CMS in teaching and learning (PdPc) in the classroom or lecture. The five emphasis is on inquirybased learning, problem solving, contextual learning, collaborative learning and project-based learning. The teaching and learning process outlined shows that the CCTS is able to move students towards the development of quality human capital.

For HOTS, the effectiveness and appropriateness of $\mathrm{PdPc}$ objectives can be achieve with various PdPc strategies. Among the strategies PdP can use are constructivism, contextual learning, project-based learning, inquiry and future research. A classroom environment that allows students to think helps with the right strategy. The teaching strategies that where been stated at the same time can help students actively build knowledge or concepts based on existing knowledge and experience. In addition, students can explore information, interpret, draw conclusions and make their own decisions. All of these strategies require students to be creative thinkers and innovators. Additionally, students will be more confident and dynamic in solving any issues or issues that arise. It is clear that while the CCTS and HOTS have very similar pedagogical approaches but different strategies, they are still aim at developing quality human capital in the future.

\subsubsection{Elements of Assessment}

Assessment is the process of obtaining information using a variety of methods and approaches, whether formative, summative, formal and informal, internal and external to obtain evidence that can be consider and subsequently judge an educational product. Assessment has been synonymous with the education system in Malaysia. Through the CCTS's thinking skills, this aspect of assessment is not focus on the MOE as it still relies on the same assessment or examination system as before. CCTS focuses only on changing aspects of curriculum and pedagogy. The assessments used to implement the CCTS only use a quantitative and formative assessment that has been conduct for a long time in the education system in Malaysia.

Higher Orders Thinking Skills (HOTS) has focused on three key elements of curriculum, pedagogy and assessment. HOTS has focused on the elements of assessment by focusing on the construction of HOTS assessment items. These assessment items have focused on testing students' ability to apply knowledge, skills and judgment in reasoning and reflection to solve problems, make decisions, innovate, and create. Thus, the HOTS item involves a wide scope, variety of stimulating and challenging methods and materials but can be assessed because basic knowledge is either learned, through experience, reading and so on as an essential prerequisite to stimulate students to think at a higher level. Student reactions are independent, non-specific, and can be across subjects. Items HOTS have all or most of the following features:

(a) Use extensive stimulus to generate critical inference and critical thinking skills.

(b) Provide students with enough information to generate ideas.

(c) Test different levels of cognitive thinking.

(d) Invites different types of responses. Based on the unusual new context. Use situations outside of the classroom. Encourage students to think 
more deeply and not just to recall what they learned in the classroom.

(e) Based on real life situations. Encourage students to use learning outcomes from various disciplines to solve everyday problems. Uses repeated items.

Items vary every year. Uses materials beyond textbooks, workbooks, training books, and more.

\subsubsection{Effectiveness of CCTS and HOTS in the Formation of Quality Human Capital}

The effectiveness of the CCTS depends on the teachers and students attending the teaching and learning sessions (PdPc) itself. Students will benefit if they understand the concept and implementation of the teaching by their teachers who use the CCTS. According to Yahya Buntat \& Norhusna Mohamed (2010), besides the application of comprehension and application of technique used in creative and critical thinking. The purpose of this study is also to examine what benefits students have when they apply their creative and critical thinking when teaching a Technical subject. The findings show that students benefit greatly from creative and critical thinking. This indicates a high level of application. Its effectiveness will enable students to develop concepts using their own methods and generate meaningful ideas in their learning. In addition, effective implementation of the CMSC can guide students to develop a variety of learning techniques and methods in understanding the content of the lessons being taught. Here it is evident that students are able to create a dynamic, creative and innovative learning environment for understanding a lesson. Judging from the findings from item 22, it was found that the majority of technical teachers $(88.3 \%)$ agreed that creative and critical thinking enabled students to develop a variety of learning alternatives to better understand the content taught (Yahya Buntat \& Norhusna Mohamed, 2010).

If HOTS's effectiveness can be achieve in today's education system, it can produce a balanced and responsible people for the country's prosperity. Students can be helped by cultivating and fostering the implementation of HOTS to perform mind-boggling operations such as analysis and inference which in turn improves their understanding and improves their achievement. Students who master the HOTS also face the challenge and dare to try new solutions. Enhanced HOTS encourage students to draw conclusions based on logic, evidence-based reading and research. Students can also make predictions based on cause and effect as well as provide solutions to rational ideas (Curriculum Development Division, KPM, 2013). In addition, effective implementation of HOTS in schools can also give rise to a generation that is quick to respond, able to communicate and work in a team, and to reflect on reasoning as well as being able to innovate and create something new.

\subsubsection{Effectiveness of HOTS in Educational Systems in Malaysia, Singapore and Indonesia.}

In the current education system, most countries have adopted the Higher Orders Thinking Challenge (HOTS) to produce students capable of facing the globalization world today. Except in developing countries in Southeast Asia such as Malaysia, Singapore and Indonesia. However, the difference is that every country has implemented it in different years. Singapore was the first country to initiate HOTS in their education system in 1980. Following Malaysia and Indonesia in 2013. The achievements and effectiveness of HOTS can be measure through the Trend in International Mathematics and Sciences Study (TIMSS) program and the Program for International Students Assessment (PISA). Both programs are to study and assist in the development of educational policies in each of its member countries. TIMSS and PISA are in fact not a test but a study conducted by international organizations to evaluate and compare the quality of education of a country. This study also helps countries around the world improve their Science and Mathematics education.

For the PISA rankings for 2009, 2012 and 2015 showed an increase in these three Southeast Asian countries. In 2009, Singapore came at second, followed by Malaysia at $57^{\text {th }}$ and Indonesia at $65^{\text {th }}$. While for 2012 , Singapore is still ahead of the top three countries, remaining at second, with Malaysia rising to $52^{\text {nd }}$ and Indonesia at $64^{\text {th }}$. The year 2015 saw Singapore continue to excel in the first place, with Malaysia rising to $46^{\text {th }}$ place and Indonesia to $62^{\text {nd }}$ place. It is clear here that HOTS is very effective in the education system of developing countries to create dynamic human capital and be able to compete against the globalization world. The improvement in the scores and position within the PISA is one of the benchmarks for the effectiveness of HOTS. Singapore is one of the countries where the top three can be test every time they take the test because they are among the countries that have long implemented the HOTS in the education system. They have transformed traditional learning systems and passive-thinking skills into studentbased learning and implemented HOTS learning such as problem solving and reasonable causes. It is important for Malaysia and Indonesia to follow the footsteps of Singapore to change the approach and implementation of the education system by adopting the HOTS element. In Malaysia, thinking skills is one of the student aspirations that must be developed by the national education system. These thinking skills have 
evolved to this day, which has highlighted the NEP elements in various aspects of the curriculum, pedagogy and assessment.

\section{Research Implications}

As the result of the findings of the paper, the implementation of the CCTS and HOTS has significantly changed the educational landscape in Malaysia. Previously, teaching and learning in the classroom was only focus on remembering and understanding a lesson, but since 1994, this has changed more to produce students who are able to use higher level thinking skills. The many aspects that are emphasized in the CCTS and HOTS are critical thinking, creative thinking and coping with situations and issues. The changes made in the national education system are great for shaping and developing quality human capital. This human capital development needs to be carried out continuously by making more investments in education that will enhance the productivity of efficient workplaces in the future. It is clear that a credible investment in education can make individuals and students especially good quality human capital. To build quality human capital, human capital development does not focus solely on the system. Hopefully that in the future, human capital development will need to be further integrated into the school's infrastructure and environment, student health, and teacher skills training in order to keep pace with the changing educational system.

\section{Conclusion}

In conclusion, Critical and Creative Thinking Skills (CCTS) and High Orders Level Thinking Skills (HOTS) have directly led to the development of quality human capital among students. High quality human capital features such as creative, innovative, dynamic, knowledgeable, confident, ethical and moral value can be achieve through the continuation of these thinking skills. HOTS is a continuation of the implementation of the CCTS was introduce in 1994. KBAT has focused on three main elements of curriculum, pedagogy and assessment, which was previously focus on curriculum and pedagogy only. The CCTS and HOTS have the same goal of producing and developing human capital for the country so that it can compete and drive the economy in today's globalized world. Effective implementation of the CCTS and HOTS will enable students to make creative and innovative decisions, create something new that will benefit to the community, not be mistaken in thinking and be a quality human capital for the country. Education is deeply embedded in Schultz's 1971 theory of human capital development in a country. So, investing in human capital through education is not a waste and a waste of time. It will even help the country improve its economy and productivity better.

\section{References}

[1] Bahagian Pembangunan Kurikulum, Kementerian Pendidikan Malaysia. 2014. Kemahiran Berfikir Aras Tinggi Aplikasi Di Sekolah.

[2] Baharom Mohamad, Mohamad Johdi Salleh. 2009. Pembangunan Modal Insan Sebagai Satu Pelaburan Penting Dalam Konteks Pembinaan Negara. Prosiding "Seminar Pembangunan Modal Insan 2009”, Tema: Kecemerlangan Modal Insan.

[3] Chew Fong Peng, Shashipriya Nadaraja. 2014. Pelaksanaan Kemahiran Berfikir Kreatif Dan Kritis Dalam Pengajaran Dan Pembelajaran Komsas Di Sekolah Menengah. Jurnal Pendidikan Bahasa Melayu - JPBM, ISSN: 2180-4842. Vol. 4, Bil. 2 (Nov. 2014): 10-24

[4] Dunia Bahasa. 29 Mac 2014. Pembangunan Modal Insan.

http://zimaupsi.blogspot.com/2014/03/pembanguna $\underline{\text { n-modal-insan.html }}$

[5] Irwan Bin Rosleh. 2010. Transformasi PTV Ke Arah Melahirkan Modal Insan Kelas Pertama.

[6] Lembaga Peperiksaan, Kementerian Pendidikan Malaysia. 2013. Pentaksiran Kemahiran Berfikir Aras Tinggi.

[7] Malini Ganapathy, Manjet Kaur Mehar Singh, Sarjit Kaur, Liew Wai Kit. 2017. Promoting Higher Order Thinking Skills via Teaching Practices. 3L: The Southeast Asian Journal of English Language Studies - Vol 23(1):75 - 85

[8] Mohd Fadzil Mohd Rosdi, Suhaida Abdul Kadir, Mohd Ibrahim Nazri. 2017. Tahap Kemahiran Dan Kecenderungan Pemikiran Kritis Murid Tingkatan Dua Dalam Mata Pelajaran Kemahiran Hidup Bersepadu (Khb) Di Negeri Kedah Dan Hubungannya. Asia Pacific Journal of Educators and Education, Vol. 32, 45-60

[9] Nik Mustapha Nik Hassan (2006). "Islam Dan Pengurusan Organisasi”. Institut Kefahaman Islam Malaysia. http://www.ikim.gov.my/v5/index.php

[10]Norain Mat Lazim, Nooriah Yusof. 2012. Universiti, Pembangunan Modal Insan Dan Penumpuan Ruang Komuniti Berpendidikan Tinggi Di Malaysia: Suatu Ulasan Kritis. Jurnal of Social Science and Humanities, Volume 7, Number 2, 308327, 2012

[11]Pusat Perkembangan Kurikulum, Kementerian Pendidikan Malaysia. April 2002. Kemahiran Berfikir Dalam Pengajaran dan Pembelajaran. 
[12] Samsul Hadi, Heri Retnawati, Sudji Munadi, Ezi Apino, Nidya F. Wulandari. 2018. The Difficulties Of High School Students In Solving Higher-Order Thinking Skills Problems. Problems Of Education In The 21st Century, Vol. 76, No. 4, 2018

[13] Sharifah Nor Puteh, Nor Adibah Ghazali, Mohd Mahzan Tamyis, Aliza Ali. 2012. Keprihatinan Guru Bahasa Melayu Dalam Melaksanakankemahiran Berfikir Secara Kritis Dan Kreatif. Jurnal Pendidikan Bahasa Melayu - JPBM, ISSN: 2180-4842. Vol. 2, Bil. 2 (Nov. 2012): 19-31

[14] Siti Ramdiah, Abidinsyah, M. Royani, Husamah. 2019. Understanding, Planning, and Implementation of HOTS by Senior High School Biology Teachers in Banjarmasin-Indonesia. International Journal of Instruction January 2019 Vol.12, No.1 e-ISSN: 1308-1470

[15] The Straits Times Singapore. 25 Disember 2016. How Singapore's students rose to No. 1-Amelia Teng. https://www.straitstimes.com/singapore/education/h ow-spores-students-rose-to-no-1

[16] Venhorst, V., Dijk, J. V. \& Wissen, L. V. 2010. Do the best graduates leave the peripheral areas of the Netherlands? Tijdschrift voor Economische en Sociale Geografie, 521-537.

[17] Yahya Buntat, Norhusna Mohamed. 2010. Aplikasi Pemikiran Kreatif Dan Kritis Dalam Pengajaran Guru-Guru Teknikal Bagi Mata Pelajaran Teknikal Di Sekolah Menengah Teknik Di Negeri Johor.

[18]Zahir Zainudin. 3 November 2006. Pendidikan dan Pembinaan modal Insan. http://zahirzainudin.blogspot.com/2006/11/pendidik an-dan-pembinaan-modal-insan.html 